\title{
Originals
}

\section{Exercise as a provocative test in early renal disease in Type 1 (insulin-dependent) diabetes: albuminuric, systemic and renal haemodynamic responses}

\author{
B. Feldt-Rasmussen ${ }^{1}$, L. Baker ${ }^{2}$ and T. Deckert ${ }^{1}$ \\ ${ }^{1}$ Steno Memorial Hospital, Gentofte, Denmark and ${ }^{2}$ Children's Hospital of Philadelphia, Philadelphia, Pennsylvania, USA
}

\begin{abstract}
Summary. The value of exercise as a provocative test for early renal disease in Type 1 (insulin-dependent) diabetes was reevaluated. Three carefully characterized groups of males were studied: 10 non-diabetic controls, 16 diabetic patients (group 1) with normal urinary albumin excretion $(<$ $15 \mu \mathrm{g} / \mathrm{min}$ ) and 14 Albustix-negative diabetics (group 2) with increased urinary albumin excretion $(15-122 \mu \mathrm{g} / \mathrm{min})$. Assignment to a study group was made on the basis of three 24-h urine collections, and the groups were well matched for age, weight, height, and serum creatinine concentration. The two diabetic groups were similar with regard to duration of disease (13 \pm 6 versus $16 \pm 3$ years), metabolic control ( $\mathrm{HbA}_{1 c}$ : $8.4 \pm 1.4$ versus $8.7 \pm 1.3 \%$ ) and degree of diabetic complications (beat-to-beat variation and retinopathy). An exercise protocol of 450 and $600 \mathrm{kpm} / \mathrm{min}$ workloads was employed. In the resting state group 2 patients had elevated systolic blood pressure compared with the normal subjects (132 \pm 13 versus $119 \pm 9 \mathrm{mmHg}$ ), and their glomerular filtration rate was significantly reduced compared with group 1 (123 \pm 19 versus $138 \pm 15 \mathrm{ml} / \mathrm{min}$ per $1.73 \mathrm{~m}^{2}, p<0.05$ ). During exercise the urinary albumin excretion rate increased significantly in all
\end{abstract}

three groups (normal subjects: $6 \pm 0.7$ to $8 \pm 1.3(\mu \mathrm{g} / \mathrm{min})$; group 1: $6 \pm 0.6$ to $9 \pm 1 \mu \mathrm{g} / \mathrm{min}$ and group 2: $48 \pm 10$ to $113 \pm 23 \mu \mathrm{g} / \mathrm{min}$ ), the relative increase being higher in group 2 $(p<0.01)$. The changes in systemic haemodynamics were similar in all three groups in spite of a reduced maximum working capacity in group 2 ( $949 \pm 249$ versus group 1: $1163 \pm 200$ and normal subjects $1267 \pm 264 \mathrm{kpm} / \mathrm{min}(p<0.05)$. The renal haemodynamic changes were qualitatively similar for the three groups, but the filtration fraction during exercise increased in groups 1 and 2 to almost identical values and were significantly higher than in normal subjects (group $1+$ group 2: $0.29 \pm 0.02$ versus normal subjects: $0.26 \pm 0.03, p<0.02$ ). These findings suggest that an elevated transcapillary pressure gradient, as obtained during moderate exercise, will not cause an abnormal increase in albumin excretion per se. A functional glomerular lesion, already recognisable at rest (elevated albumin excretion) must also be present.

Key words: Type 1 diabetes, incipient nephropathy, exercise, albuminuria, renal haemodynamics, glomerular filtration rate, blood pressure, working capacity.
The exercise provocative test was introduced for detection of early changes in diabetic renal disease by Mogensen and co-workers in the early 1970s [1]. Specifically, moderate physical exercise could cause increased urinary albumin excretion $\left(\mathrm{U}_{\mathrm{alb}} \mathrm{V}\right)$ in patients with Type 1 (insulin-dependent) diabetes, who had normal levels of $U_{\mathrm{alb}} \mathrm{V}$ in the resting basal state. Their observations were confirmed by others [2], but were also subject to criticism [3, 4]. Recently, the relative increase in $U_{\mathrm{alb}} \mathrm{V}$ during exercise was found to be equal in patients with either normal or elevated baseline $U_{\mathrm{alb}} \mathrm{V}$ [5]. This observation indicated that minor abnormalities in the glomerular handling of albumin might already be recognisable at rest. The discrepancies between the observations in these previous studies cannot readily be explained, but differences in the way the exercise test was adminis- tered and in the composition of the study groups make comparisons difficult.

The mechanism underlying exercise induced albuminuria is unknown. The glomerular filtration rate (GFR), the renal plasma flow (RPF) and the filtration fraction are signifcantly elevated in diabetic patients from the time of diagnosis compared with normal subjects [6-9]. It has been speculated that a further exaggeration of the abnormal renal haemodynamics may be responsible for the exercise-induced increase in $\mathrm{U}_{\mathrm{alb}} \mathrm{V}$ [10]. Furthermore, a positive correlation between exercise-induced systolic pressure and exercise-induced $\mathrm{U}_{\mathrm{alb}} \mathrm{V}$ has been demonstrated [5].

Thus the exercise test may be of importance as a diagnostic test as well as a tool for investigating systemic 
Table 1. Clinical characteristics of the study groups

\begin{tabular}{|c|c|c|c|c|c|c|c|c|}
\hline & $\begin{array}{l}\text { Age } \\
\text { (years) }\end{array}$ & $\begin{array}{l}\text { Height } \\
\text { (cm) }\end{array}$ & $\begin{array}{l}\text { Weight } \\
(\mathrm{kg})\end{array}$ & $\begin{array}{l}\text { Serum- } \\
\text { creatinine } \\
(\mu \mathrm{mol} / 1)\end{array}$ & $\begin{array}{l}\text { Diabetes } \\
\text { duration } \\
\text { (years) }\end{array}$ & $\begin{array}{l}\mathrm{HbA}_{1 \mathrm{c}} \\
(\%)\end{array}$ & $\begin{array}{l}\text { Beat-to- } \\
\text { beat } \\
\text { variation } \\
\text { (per min) }\end{array}$ & $\begin{array}{l}\text { Retino- } \\
\text { pathy }^{\mathrm{a}}\end{array}$ \\
\hline $\begin{array}{l}\text { Normal subjects } \\
(n=10)\end{array}$ & $\begin{array}{c}35 \pm 8 \\
(28-53)\end{array}$ & $\begin{array}{c}180 \pm \quad 6 \\
(169-187)\end{array}$ & $\begin{array}{c}71 \pm 6 \\
(64-83)\end{array}$ & $\begin{array}{c}91 \pm 10 \\
(85-111)\end{array}$ & - & - & - & - \\
\hline $\begin{array}{l}\text { Diabetic patients with urinary } \\
\text { albumin excretion }<15 \mu \mathrm{g} / \mathrm{min} \\
\text { (Group 1) } \\
(n=16)\end{array}$ & $\begin{array}{c}32 \pm 6 \\
(19-40)\end{array}$ & $\begin{array}{c}178 \pm 5 \\
(177-188)\end{array}$ & $\begin{array}{c}75 \pm 7 \\
(71-89)\end{array}$ & $\begin{array}{c}88 \pm 10 \\
(77-108)\end{array}$ & $\begin{array}{l}13 \pm 6 \\
(6-24)\end{array}$ & $\begin{array}{c}8.4 \pm 1.4 \\
(6.0-11.0)\end{array}$ & $\begin{array}{l}19 \pm 8 \\
(3-38)\end{array}$ & $7 / 9 / 0$ \\
\hline $\begin{array}{l}\text { Diabetic patients with urinary } \\
\text { albumin excretion }>15 \mu \mathrm{g} / \mathrm{min} \\
\text { (Group } 2) \\
(n=14)\end{array}$ & $\begin{array}{c}33 \pm 7 \\
(20-47)\end{array}$ & $\begin{array}{c}178 \pm 6 \\
(171-185)\end{array}$ & $\begin{array}{c}72 \pm 7 \\
(57-80)\end{array}$ & $\begin{array}{c}88 \pm 10 \\
(77-105)\end{array}$ & $\begin{array}{c}16 \pm 3 \\
(10-22)\end{array}$ & $\begin{array}{c}8.7 \pm 1.3 \\
(6.7-11.3)\end{array}$ & $\begin{array}{l}18 \pm 10 \\
(4-33)\end{array}$ & $5 / 9 / 0$ \\
\hline
\end{tabular}

Values given as mean \pm SD with range in parenthesis. No significant differences between the groups.

a $<3$ microaneurisms/simplex retinopathy/proliferative retinopathy

and renal haemodynamic abnormalities in early diabetic renal diseases.

The present study was undertaken to re-evaluate the albuminuric response to exercise in Type 1 diabetic patients with normal and elevated $\mathrm{U}_{\mathrm{alb}} \mathrm{V}$ compared with normal subjects. Systemic and renal haemodynamics were also studied.

\section{Subjects and methods}

\section{Patient recruitment and selection}

Thirty adult male Type 1 diabetic patients were studied. Ten age matched non-diabetic males served as controls. The patients were chosen on the basis of duration of diabetes (5-25 years), Albustix-negative urine, normal serum creatinine level, and negative urine culture. All patients gave informed consent for their participation, and the study was approved by the Regional Medical Ethics Committee.

The patients were subdivided into two groups according to their level of albuminuria, identified on the basis of the mean $U_{\text {alb }} V$ in three 24-h urine collections performed at home during normal activity. This was done to take into account the large $(50 \%)$ coefficient of variation of the 24-h urinary albumin excretion rate $\left(U_{a l b} V\right)[11,12]$. Sixteen patients formed group 1 and were defined as normoalbuminuric, with a $\mathrm{U}_{\mathrm{alb}} \mathrm{V}$ of $<15 \mu \mathrm{g} / \mathrm{min}$. The 14 patients in group 2 were characterized by elevated $U_{a l b} V$ with the mean $U_{a l b} V$ of three 24-h urine samples ranging from $15-122 \mu \mathrm{g} / \mathrm{min} ; 12$ of these patients were in the lower range of microalbuminuria with $U_{\text {alb }} V<60 \mu \mathrm{g} / \mathrm{min}$. The distribution of $\mathrm{U}_{\mathrm{alb}} \mathrm{V}$ in 24-h urine samples of 239 normal subjects is skewed (median $6.1,95 \%$ percentiles: $1.1-24 \mu \mathrm{g} / \mathrm{min}$ ) [13]. The chosen level of $15 \mu \mathrm{g} / \mathrm{min}$ is the same as used recently by Christensen [5], slightly above the level used by Viberti et al. [2], but consistent with a previously suggested definition of incipient nephropathy [14]. Patient and control data are shown in Table 1 . The groups were well matched for age, weight, height, and serum creatinine. The two diabetic groups did not differ significantly with regard to duration of disease, level of metabolic control, and degree of diabetic complications.

\section{The exercise protocol}

The exercise protocol of Mogensen et al. [14] was used for these studies. The patients reported to the exercise laboratory at $08.00 \mathrm{~h}$ in the fasting state, the most recent insulin dose having been given before supper the previous evening. Alcohol and tobacco were proscribed for at least $12 \mathrm{~h}$ before the study. A cannula was inserted into an ante- cubital vein in each arm. After careful attention to the achievement of steady state water diuresis [15], two basal timed urine specimens ( 20 $\mathrm{min}$ each) were collected. The patient was exercised at $450 \mathrm{kpm} / \mathrm{min}$ (W 450), and then at $600 \mathrm{kpm} / \mathrm{min}$ (W600) for $20 \mathrm{~min}$; a timed urine was obtained at the end of each period. Two post-exercise recovery periods of $20 \mathrm{~min}$ were each accompanied by urine collections. The patients sat in chairs except when voiding or exercising. The exercise load was performed on a mechanically braked electronically controlled ergometercycle (Monark, model 669-1, Varberg, Sweden).

\section{Systemic haemodynamics}

The blood pressure was measured by the indirect auscultatory method, using a sphygmomanometer and cuff. The blood pressure was measured twice in the middle of each period, and also after $15 \mathrm{~min}$ of exercise at each of the two work loads. During exercise the diastolic pressure as assessed by this method is not reliable [16] and is therefore not reported. The heart rate was recorded from surface electrodes, and the mean heart rate in 20 -s periods was calculated.

\section{Renal haemodynamic measurements}

The GFR was measured by the classical constant infusion technique with urinary collections [17] using ${ }^{125} \mathrm{I}$-iothalamate as the filtration marker [18]. The results were corrected to a body surface area of $1.73 \mathrm{~m}^{2}$. The intra-assay coefficient of variation in our laboratory was $4.1 \%$. The RPF was defined as the extraction of hippuran, using ${ }^{131} \mathrm{I}$ hippuran [18]. This has been shown to be a reliable technique for renal plasma flow, even during exercise [19]. These results were also corrected to a body surface area of $1.73 \mathrm{~m}^{2}$. The intra-assay coefficient of variation was $4.3 \%$. The filtration fraction was calculated as GFR RPF.

\section{Maximal working capacity}

The maximal working capacity was determined at the end of the formal exercise study, approximately $60 \mathrm{~min}$ after completion of the $600 \mathrm{kpm} / \mathrm{min}$ work load. The patients were allowed 5 min to warm up at a work load of $450-600 \mathrm{kpm} / \mathrm{min}$. The work load was then increased stepwise until the patient became exhausted. Each work load was maintained for $2 \mathrm{~min}$, or until the heart rate was stable in consecutive 20 -s periods. At high work loads, this procedure ensures the achievement of steady state conditions, and a good correlation between heart rate and oxygen uptake [20]. The work load at which maximal oxygen uptake will occur $\mathrm{W}_{\max } \mathrm{O}_{2}$ ) was calculated from the following equation:

$\mathrm{W}_{\max } \mathrm{O}_{2}=\mathrm{W} 600 \times \frac{\text { maximal heart rate - basal heart rate }}{\text { heart rate at } 600 \mathrm{kpm} / \mathrm{min} \text { - basal heart rate }}$ 


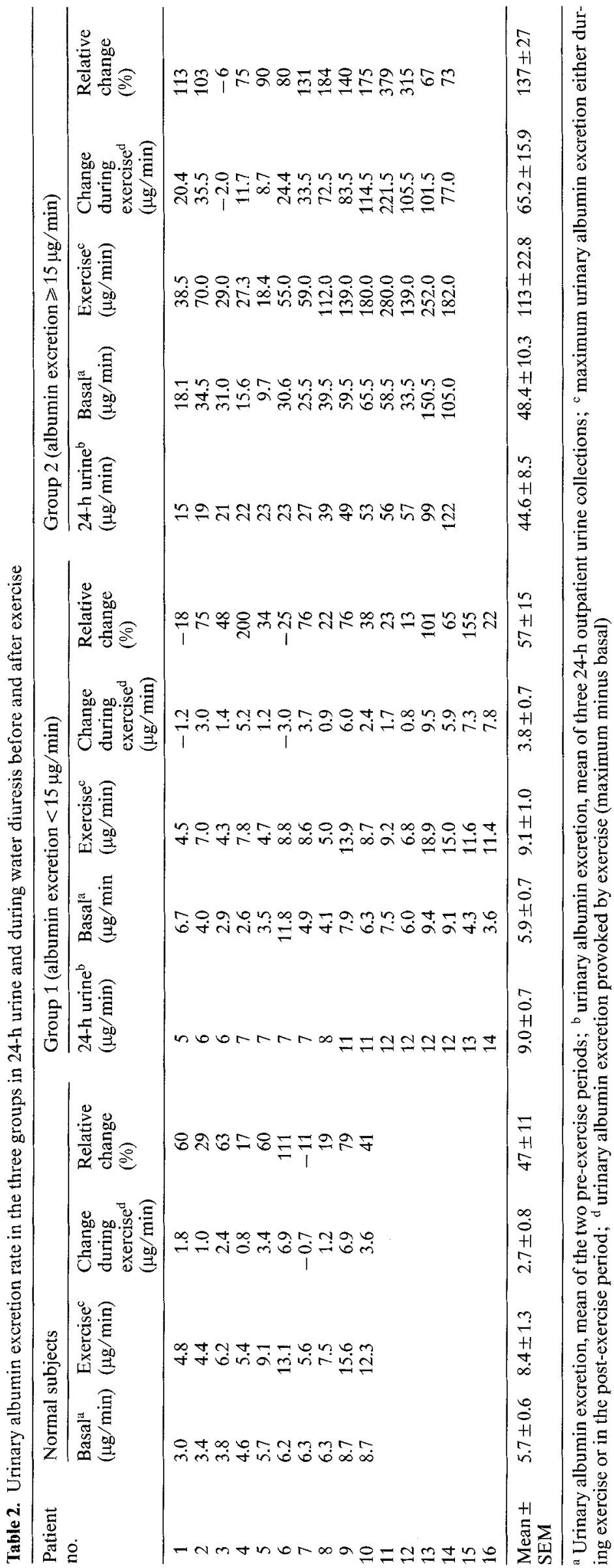

\section{Laboratory measurements}

$\mathrm{HbA}_{1 \mathrm{c}}$ was measured by a chromatographic technique [21]; values for the non-diabetic for this procedure are $4.1 \%-6.4 \%$. Urinary albumin was measured by radioimmunoassay [22]. Beat-to-beat variation was assessed according to Ewing and Clark [23]. Classification of retinopathy was done on the basis of ophthalmoscopy through the dilated pupil.

\section{Statistical methods}

Albumin data were $\log _{10}$ transformed and then, as with the systemic and renal haemodynamic results, analyzed using the paired and unpaired $t$-test (two tailed). A linear regression analysis was used to examine correlations.

\section{Results}

\section{Baseline data}

All values presented represent the mean of two preexercise basal periods. The patients had been characterized according to $\mathrm{U}_{\mathrm{alb}} \mathrm{V}$ levels in 24-h urine collections. This value correlated with $\mathrm{U}_{\mathrm{alb}} \mathrm{V}$ during water diuresis on the day of study $(r=0.93, y=-3.0+1.1 x)$. In consequence, the albuminuric levels in the two groups were confirmed except for patient 5 , group 2 , found to be excreting $10 \mu \mathrm{g} / \mathrm{min}$ at the time of the study (Table 2). The basal heart rate in group 1 was elevated compared with the normal subjects $(p<0.02)$. The heart rate in group 2 was between the other two groups and statistically indistinguishable (Table 3). The systolic blood pressure in group 2 was significantly elevated compared with the control group (Table 3).

The GFR values at rest are shown in Figure 1. The GFR was elevated in both diabetic groups compared with the normal subjects. The GFR in the normoalbuminuric group was significantly above that seen in the microalbuminuric group $(138 \pm 15$ versus $123 \pm$ $19 \mathrm{ml} / \mathrm{min}$ per $1.73 \mathrm{~m}^{2}, p<0.05$ ). The three patients in group 2 with the lowest GFR values had mean 24-h $\mathrm{U}_{\mathrm{alb}} \mathrm{V}$ levels of 19,54 , and $27 \mu \mathrm{g} / \mathrm{min}$. These patients and the three group 1 patients with the lowest GFR values all had autonomic neuropathy (beat-to-beat variations $<15$ per min), but were in better metabolic control compared with the other patients (all six patients had $\mathrm{HbA}_{1 \mathrm{c}}$ levels <8.3\%). The RPF values differed between groups 1 and $2(603 \pm 61$ versus $543 \pm$ $74 \mathrm{ml} / \mathrm{min}$ per $1.73 \mathrm{~m}^{2}, p<0.05$ ); the calculated filtration fraction (GFR/RPF) was similar in the two groups.

\section{Systemic haemodynamic response to exercise}

Five of the diabetic patients, four in group 1 and one in group 2, failed to initiate voiding within the first minute after the $600 \mathrm{kpm} / \mathrm{min}$ workload. Since urine albumin excretion is high in both the exercise void and the first post exercise urine, $\mathrm{U}_{\mathrm{alb}} \mathrm{V}$ is not very sensitive to this delay. On the other hand, renal haemodynamics change 
Table 3. Basal clinical data and data on maximum working capacity test

\begin{tabular}{|c|c|c|c|c|c|c|c|c|}
\hline \multirow[b]{3}{*}{$\begin{array}{l}\text { Normal subjects } \\
(n=10)\end{array}$} & \multirow{3}{*}{$\begin{array}{l}\begin{array}{l}\text { Age } \\
\text { (years) }\end{array} \\
35 \pm 8\end{array}$} & \multirow{3}{*}{$\begin{array}{l}\begin{array}{l}\text { Diabetes } \\
\text { duration } \\
\text { (years) }\end{array} \\
-\end{array}$} & \multicolumn{2}{|l|}{ Heart rate } & \multicolumn{2}{|c|}{ Basal Blood Pressure } & \multirow{3}{*}{$\begin{array}{l}\begin{array}{l}\text { Maximum } \\
\text { work load } \\
(\mathrm{kpm} / \mathrm{min})\end{array} \\
1501 \pm 234\end{array}$} & \multirow{3}{*}{$\begin{array}{l}\mathrm{W}_{\max } \mathrm{O}_{2} \\
(\mathrm{kpm} / \mathrm{min}) \\
1267 \pm 264\end{array}$} \\
\hline & & & \multirow{2}{*}{$\begin{array}{l}\begin{array}{l}\text { basal } \\
\text { (beats/min) }\end{array} \\
58 \pm 7\end{array}$} & \multirow{2}{*}{$\frac{\begin{array}{l}\text { maximal } \\
\text { (beats } / \mathrm{min})\end{array}}{176 \pm 15}$} & \multirow{2}{*}{$\frac{\begin{array}{c}\text { systolic } \\
(\mathrm{m} 1\end{array}}{119 \pm 9}$} & $\begin{array}{l}\text { diastolic } \\
\text { Ig) }\end{array}$ & & \\
\hline & & & & & & $81 \pm 6$ & & \\
\hline $\begin{array}{l}\text { Diabetic patients with } \\
\text { urinary albumin excretion } \\
<15 \mu \mathrm{g} / \min \text { (Group } 1) \\
(n=12)\end{array}$ & $31 \pm 7$ & $11 \pm 4^{\mathrm{c}}$ & $70 \pm 8^{a}$ & $177 \pm 12$ & $126 \pm 9$ & $85 \pm 7$ & $1352 \pm 127^{\mathrm{a}}$ & $1163 \pm 200$ \\
\hline $\begin{array}{l}\text { Diabetic patients with } \\
\text { urinary albumin excretion } \\
\geqslant 15 \mu \mathrm{g} / \mathrm{min} \text { (Group } 2) \\
(n=13)\end{array}$ & $34 \pm 7$ & $16 \pm 3^{c}$ & $64 \pm 12$ & $162 \pm 12^{\mathrm{c} b}$ & $132 \pm 13$ & $82 \pm 8$ & $1162 \pm 322^{b}$ & $949 \pm 949^{c b}$ \\
\hline
\end{tabular}

Values given as mean \pm SD. Differences between groups considered significant when $p<0.05$ (two tailed).

${ }^{a}$ Significant differences between normal subjects and group $1 ;{ }^{b}$ significant differences between normal subjects and group $2 ;{ }^{c}$ significant differences between group 1 and group 2

This table includes normal subjects and the 25 patients who completed the renal haemodynamic study (five patients are missing (compare Tables 1 and 2) as explained in the text)

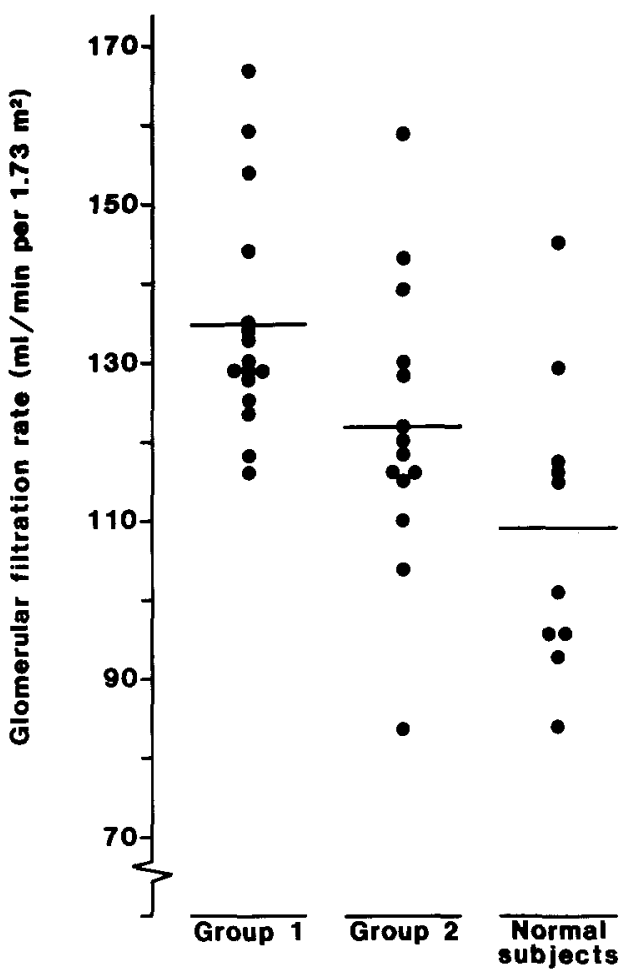

Fig. 1. Basal glomerular filtration rate in young Type 1 diabetic patients with (group $1, n=14$ ) and without (group 2, $n=16$ ) microalbuminuria (urinary albumin excretion rate $>15 \mu \mathrm{g} / \mathrm{min}$ ), and in healthy subjects $(n=10)$. Horizontal bars indicate mean values. Difference between group 1 and group 2, $p<0.05$. Difference between normal subjects and group $2, p<0.05$

rapidly. These measurements are dependent on a close time relationship between exercise and urine collections. Therefore, patient 5,9,11, and 13 in group 1 and patient 3 in group 2 (Table 2) were excluded from the analyses of the renal haemodynamics during exercise. The duration of diabetes of these patients was slightly longer (10-24 years). They did not differ with regard to the other variables, nor with regard to metabolic control during exercise.

During exercise, blood glucose levels were basically unchanged, between the diabetic groups (Table 4). Two patients vomited before exercise due to excess water load. They had no ketonuria and felt comfortable enough to continue the test.

Urine flow was very similar in the three groups at rest, but was significantly reduced during exercise in all three groups $(p<0.01)$. There was no difference between the two diabetic groups (Table 4).

When tested for maximal working capacity, the microalbuminuric group achieved a maximal heart rate of $162 \pm 12$ beats $/ \min (p<0.05)$ lower than seen in the normoalbuminuric group $(177 \pm 12)$ or the non-diabetic subjects $(176 \pm 15)$. However, the fixed work load of $600 \mathrm{~km} / \mathrm{min}$ represented a significantly greater stress for the patients in group 2 (Table 5). The actual maximal work load performed by group 2 was $1162 \pm$ $322 \mathrm{kpm} / \mathrm{min}$, which was significantly lower than seen in normal subjects $(1501 \pm 234, p<0.05)$. In this instance, group $1(1352 \pm 127 \mathrm{kpm} / \mathrm{min})$ was also significantly different from normal, but calculation of $\mathrm{W}_{\max } \mathrm{O}_{2}$, a more reliable indicator of maximal working capacity, revealed that group $2(949 \pm 249 \mathrm{kpm} / \mathrm{min})$ was significantly lower than both group $1(1163 \pm 200)$ and the control subjects $(1267 \pm 264)$; the differenze between group 1 and non-diabetic subjects was no longer significant (Table 3 ).

During the exercise provocative test, the $600 \mathrm{kpm} /$ min workload elicited almost identical heart rates $(126 \pm 17,127 \pm 21$ beats $/ \mathrm{min})$ and systemic blood pressures $164 \pm 12,167 \pm 17 \mathrm{mmHg}$ ) in groups 1 and 2, respectively. These values were not significantly higher, than those obeobserved in normal subjects (115 \pm 10 beats $/ \mathrm{min}, 155 \pm 17 \mathrm{mmHg}$ ).

Furthermore, the changes in heart rate and systolic blood pressure were similar for all groups (Table 5). 
Table 4. Urine flow and blood glucose concentrations before and during exercise

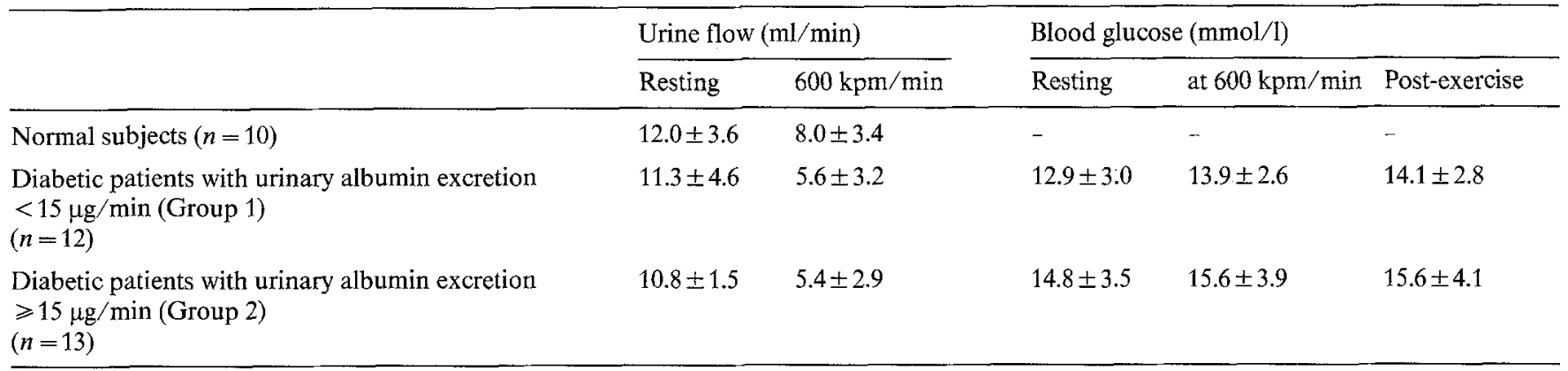

Table 5. Systemic and renal haemodynamic responses to exercise $(600 \mathrm{kpm} / \mathrm{min})$

\begin{tabular}{|c|c|c|c|c|c|c|c|c|}
\hline & $\begin{array}{l}\text { Urinary albu- } \\
\text { min excretion } \\
\text { basal }\left(U_{\mathrm{alb}} \mathrm{V}\right) \\
(\mu \mathrm{g} / \mathrm{min})\end{array}$ & $\begin{array}{l}\Delta \mathrm{U}_{\mathrm{alb}} \mathrm{V} \\
(\mu \mathrm{g} / \mathrm{min})\end{array}$ & $\begin{array}{l}600 \mathrm{kpm} / \mathrm{min} \\
\text { as relative } \\
\text { work load } \\
(\%)\end{array}$ & $\begin{array}{l}\Delta \text { Heart rate } \\
\text { (beats } / \mathrm{min} \text { ) }\end{array}$ & $\begin{array}{l}\triangle \text { Systolic } \\
\text { blood pres- } \\
\text { sure }(\mathrm{mmHg})\end{array}$ & $\begin{array}{l}\triangle \mathrm{GFR} \\
(\%)\end{array}$ & $\begin{array}{l}\triangle \mathrm{RPF} \\
(\%)\end{array}$ & $\begin{array}{l}\Delta \text { Filtration } \\
\text { fraction }(\%)\end{array}$ \\
\hline $\begin{array}{l}\text { Normal subjects } \\
(n=10)\end{array}$ & $5.7 \pm 2.0$ & $2.8 \pm 2.5$ & $49 \pm 11$ & $57 \pm 9$ & $36 \pm 12$ & $12 \pm 12$ & $27 \pm 12$ & $19 \pm 9$ \\
\hline $\begin{array}{l}\text { Diabetic patients } \\
\text { with urinary al- } \\
\text { bumin excretion } \\
<15 \mu \mathrm{g} / \mathrm{min} \\
(\text { Group } 1) \\
(n=12)\end{array}$ & $5.5 \pm 2.7$ & $2.9 \pm 3.3$ & $53 \pm 11$ & $56 \pm 16$ & $38 \pm 12$ & $18 \pm 10$ & $34 \pm 11$ & $25 \pm 14$ \\
\hline $\begin{array}{l}\text { Diabetic patients } \\
\text { with urinary al- } \\
\text { bumin excretion } \\
\geqslant 15 \mu \mathrm{g} / \mathrm{min} \\
(\text { Group } 2) \\
(n=13)\end{array}$ & $49.7 \pm 39.7^{\mathrm{a} b}$ & $70 \pm 59^{\mathrm{a} b}$ & $68 \pm 20^{\mathrm{a} b}$ & $62 \pm 15$ & $36 \pm 13$ & $21 \pm 9^{\mathrm{a}}$ & $36 \pm 9^{a}$ & $28 \pm 7^{\mathrm{a}}$ \\
\hline
\end{tabular}

Values given as mean \pm SD. Differences between groups considered significant when $p<0.05$ (two tailed).

${ }^{a}$ Significant differences between normal subjects and group $2 ;{ }^{b}$ significant differences between group 1 and group 2

\section{Albuminuric response}

The $\mathrm{U}_{\mathrm{alb}} \mathrm{V}$ seen after exercise provocation was the same in group 1 as in the normal group (Table $2, p<0.01$ ). In group 2 the abnormal basal $\mathrm{U}_{\mathrm{alb}} \mathrm{V}$ was further exacerbated by exercise. Both maximum $\mathrm{U}_{\mathrm{alb}} \mathrm{V}$ and absolute as well as relative change in $\mathrm{U}_{\mathrm{alb}} \mathrm{V}$ provoked by exercise were higher in this group compared with either of the other two groups $(p<0.01)$. A significant correlation was found between the basal $\mathrm{U}_{\mathrm{alb}} \mathrm{V}$ and exercise-induced increase in $\mathrm{U}_{\mathrm{alb}} \mathrm{V}$ in group $2(r=0.89, p<0.001)$.

\section{Renal haemodynamic response}

The renal haemodynamic changes during exercise were qualitatively similar for the three groups (Fig.2). The percentage reduction in GFR and RPF was greater in the diabetic groups, especially in group 2 , where it reached statistical significance $(p<0.05$, Table 5). This corresponds to the higher relative work load represented by $600 \mathrm{kpm} / \mathrm{min}$ in this group $(68 \pm 20 \%$ of maximum work capacity) when compared with group 1 $(53 \pm 11 \%)$ or normal subjects $(49 \pm 11 \%)$ (Table 5$)$. This relationship ( $\Delta$ GFR and $\Delta$ RFP versus $600 \mathrm{kpm}$ as a relative work load) appeared to be consistent, although it could not be expressed as a liniear correlation.

As previously noted, the filtration fraction in the basal state was slightly elevated in the diabetic group, but not significantly so when compared with the normal subjects. During exercise, however, the filtration fraction seen in the diabetic patients was significantly higher than that recorded for the non-diabetic control subjects $(0.292 \pm 0.02$ versus $0.260 \pm 0.012, p<0.03)$. The filtration fraction for group $2(0.294 \pm 0.02)$ was virtually identical to that seen in group $1(0.290 \pm 0.03)$, despite the large difference between the two groups in the absolute and relative changes in the urinary albumin excretion rate $\left(\Delta \mathrm{U}_{\mathrm{alb}} \mathrm{V}\right)$ provoked by exercise (Tables 2 and 5).

No significant correlations were found between the $\Delta \mathrm{U}_{\mathrm{alb}} \mathrm{V}$ and any of the renal haemodynamic variables. There was also no correlation between $\Delta \mathrm{U}_{\mathrm{alb}} \mathrm{V}$ and $\Delta$ blood pressure. The only significant correlation between systemic and renal haemodynamic changes was found in the $\Delta$ blood pressure and $\triangle \mathrm{RPF}$ in group 2 $(r=0.66, p<0.05)$. 

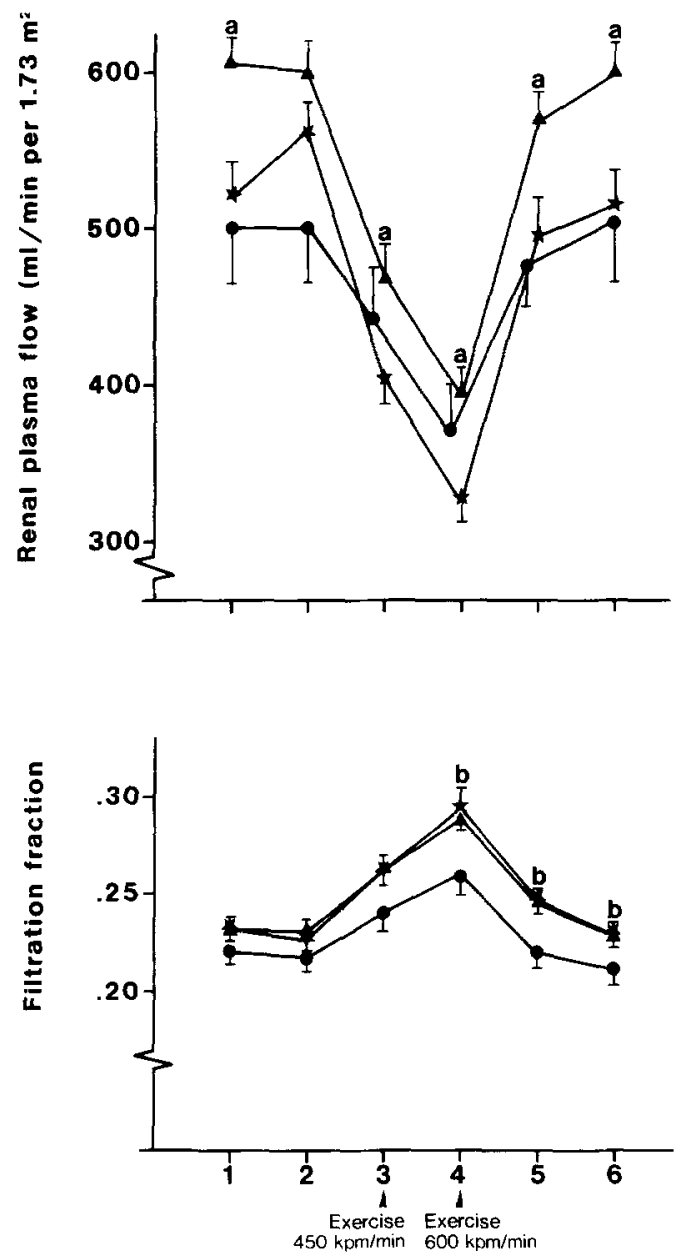

Fig. 2. A Glomerular filtration rate. B Renal plasmaflow and C filtration fraction before, during and after physical exercise in young Type 1 diabetic patients and normal subjects (mean \pm SEM). On the horizontal axis 20 -min periods are marked. Normal subjects $(n=10)$. A Diabetic patients with normal urinary albumin excretion $<15 \mu \mathrm{g} / \min$ (group 1, $n=12$ ). $*$ Diabetic patients with urinary albumin excretion $\geqslant 15 \mu \mathrm{g} / \mathrm{min}$ (group $2, n=13$ ). ${ }^{\mathrm{a}}$ Difference between group 1 and group $2(p<0.05)$, ${ }^{b}$ Difference between normals and group 1 as well as group $2(p<0.05)$. A Group 1 and the normal subjects differ significantly throughout the test $(p<0.05)$. B No significant difference between normal subjects and group 2

\section{Discussion}

The data in this study indicate that those diabetic patients who demonstrate a $U_{\text {alb }} V$ which is normal $(<$ $15 \mu \mathrm{g} / \mathrm{min}$ ) respond to exercise with an increase in $\mathrm{U}_{\mathrm{alb}} \mathrm{V}$ which is not significantly different from that seen in non-diabetic individuals. Normal subjects have often been reported not to increase $\mathrm{U}_{\mathrm{alb}} \mathrm{V}$ at this exercise level $[1,2,5]$. This may be due to differences in the interpretation of the exercise induced $\mathrm{U}_{\mathrm{alb}} \mathrm{V}$.

The maximal $\mathrm{U}_{\mathrm{alb}} \mathrm{V}$ may occur when patients are resting during the first post-exercise periods, as well as immediately following the $600 \mathrm{kpm} / \mathrm{min}$ workload. We have reported the highest value obtained in any of these periods. If this procedure is applied to the data in the study by Viberti et al. [2], his normal subjects also increased $U_{\text {alb }} V$ significantly. Data are not available for the other studies cited. The reason why maximal $\mathrm{U}_{\mathrm{alb}} \mathrm{V}$ may occur in the post-exercise period is unknown. It could be speculated that some of the albumin filtered in excess during exercise (when urine production is low) is retained in the tubular system and then washed out, when urine production is rapidly increased following exercise. A washout phenomenon is described during the initiation of water-diuresis in the resting state [15]. Exercise did appear to exaggerate further albuminuria in patients who already were known to demonstrate an increased $\mathrm{U}_{\mathrm{alb}} \mathrm{V}$ during basal conditions, thus confirming the work of Christensen [5]. However, even in this group some of the patients demonstrated a very modest increase in $\mathrm{U}_{\mathrm{alb}} \mathrm{V}$, not distinguishable from the increase observed in group 1 . Thus group 2 patients, who from several studies $[24,25,26,27]$ are known to be at high risk for the later development of overt diabetic nephropathy, in many cases have a "normal" albuminuric response to exercise. The diagnostic value of an abnormal response among group 1 patients would, on these grounds, be difficult to interpret. We therefore believe that this laborious test has no place in diagnosing early diabetic renal disease. However, our results indicate that exercise is an interesting tool. Group 2 had a significantly higher maximal $\mathrm{U}_{\mathrm{abb}} \mathrm{V}$ compared with the other groups, both in absolute and relative terms. Christensen [5] found no difference in the relative increase of $U_{a l b} V$ between patients with normal and elevated $U_{a l b} V$. We cannot offer any explanation for this discrepancy, but the renal disease in his patients was more advanced, as judged from their basal $\mathrm{U}_{\mathrm{alb}} \mathrm{V}$ levels.

The difference in the response to exercise observed in our study between the two diabetic groups might be explained by the fact that the fixed work-load of $600 \mathrm{kpm} / \mathrm{min}$ constituted a greater fraction of the maximal working capacity in group 2 patients. The $600 \mathrm{kpm} /$ min work-load therefore represented a significantly greater stress for them. However, the difference in working capacity was not reflected in a differential increase in heart rate or systolic blood pressure. On the contrary, the systemic haemodynamic response to exercise was 
similar in both diabetic groups (Table 5). It might be speculated that this indicated impaired sympathetic outflow in the group 2 patients, but the only objective data regarding this issue demonstrate no differences between the diabetic groups in beat-to-beat variation.

The renal haemodynamic responses to exercise was similar in the two diabetic groups. The somewhat larger changes in GFR and RPF in group 2 did reach statistical significance when compared with the normal control group, and probably reflect the greater relative work-load experienced by these patients. Mogensen and colleagues found that diabetic patients who demonstrated a significant increase in $\mathrm{U}_{\mathrm{alb}} \mathrm{V}$ upon exercise provocation had a filtration fraction which was significantly elevated when compared with non-diabetic subjects [10]. The data presented here confirm that the filtration fraction during exercise in the diabetic subjects was significantly above that found in normal subjects. However, despite the enormous difference between groups 1 and 2 in terms of the functional consequences of exercise $\left(\Delta \mathrm{U}_{\mathrm{alb}} \mathrm{V}\right)$, the filtration fraction in these two groups at $600 \mathrm{kpm} / \mathrm{min}$ was nearly identical. If the elevation during exercise of the filtration fraction can reasonably be interpreted as representing an increase in transglomerular pressure, then these data indicate that an elevation of transglomerular hydraulic pressure to the levels achieved at $600 \mathrm{kpm} / \mathrm{min}$ will only be followed by a significant increase in $\mathrm{U}_{\mathrm{alb}} \mathrm{V}$ when the glomerular membrane has already demonstrated impaired properties of permeability (i.e. an elevated basal $U_{\mathrm{alb}} \mathrm{V}$ ). The fact that the two diabetic groups had levels of filtration fractions which were nearly identical, both in the basal state and with exercise, also indicates that the increase in $\mathrm{U}_{\mathrm{alb}} \mathrm{V}$ seen in diabetic patients with incipient nephropathy is not dependent on a transglomerular pressure which is increased above that seen in patients with normal rates of albumin excretion. The elevation of the filtration fraction during exercise (or during normal daily activity) may play an important role in the progression of diabetic nephropathy in those patients who already demonstrate abnormalities in the glomerular handling of albumin. This would be in agreement with the observations of Parving et al. [28] and Mogensen [29]. They were able to lower $U_{a l b} V$ in patients with diabetic nephropathy who were aggressively treated for hypertension. In these patients renal autoregulation is impaired [30]. Therefore it is likely that a lowered systemic blood pressure is also accompanied by reduced transglomerular pressure resulting in reduced $\mathrm{U}_{\mathrm{aib}} \mathrm{V}$.

The state of diabetic renal disease preceding overt nephropathy has been termed "incipient nephropathy" [14]. It is characterized by an elevation of basal $U_{a b b} V$ at a time when the serum creatinine level is normal and the Albustixtest for urinary protein is negative. Retrospective studies suggest that these patients are at a much higher risk for developing full-blown clinical nephropa- thy than subjects whose basal $U_{\text {alb }} V$ is normal [24-27]. Our data extend these observations further and suggest that patients with incipient nephropathy may be different from age- and duration-matched diabetic patients with normal $\mathrm{U}_{\mathrm{alb}} \mathrm{V}$ in several important aspects other than the rate of albumin excretion. The patients in this study with incipient nephropathy had a significantly lower maximum working capacity, and a significnatly elevated basal systolic blood pressure when compared with normal subjects. This observation concerning the significant elevation of blood pressure (while still within the normal range) corroborates our findings in a previous cross-sectional study [25] and those of Wiseman et al. [31]. In addition, the levels of GFR and RPF in these microalbuminuric patients were significantly lower than those observed in those with a normal $\mathrm{U}_{\mathrm{alb}} \mathrm{V}$, even though the levels were still elevated when compared with controls. This difference could not be explained on the basis of sex, age, height, weight, duration of diabetes, degree of diabetic control, or presence of other diabetic complications. Patients with normoalbuminuria under the usual insulin treatment programs demonstrated an elevated GFR [6-9]; patients with early overt diabetic nephropathy (persistent proteinuria $>$ $0.5 \mathrm{~g} / 24 \mathrm{~h}$, but normal serum creatinine concentration) generally have normal GFR values [28, 29]. If hyperfiltration is a primary factor in the initiation of diabetic nephropathy as suggested by others $[32,33]$, then the data presented here suggest that a change in renal function (from hyperfiltration to normal rates of filtration to deterioration) may occur as the patient passes across an important threshold into the stage of incipient nephropathy characterized by persistent microalbuminuria. This finding is different from what has been previously reported. In our own cross sectional study of the GFR of a smaller group of patients [25], no significant difference was observed when comparing patients with normal $U_{\mathrm{alb}} \mathrm{V}$ versus those with microalbuminuria. Wiseman et al. [31] also found that the GFR of patients with microabluminuria was not significantly different from that observed in patients with normal rates of urinary albumin excretion, although the mean values was lower. This difference in results might be due to the more rigorous approach (mean $U_{\mathrm{alb}} V$ of three 24-h urine collections) used in this study to classify patients into groups with normal or elevated $\mathrm{U}_{\mathrm{alb}} \mathrm{V}$. In planning future studies to confirm this important observation it would seem prudent to categorize patients only on the basis of several (at least three) 24-h urine collections over a period of 1-3 months. Patients who demonstrate persistent microalbuminuria under these conditions should be used in prospective studies to trace the true natural history of incipient nephropathy.

Acknowledgements. this work was performed while Dr. L. Baker was a Fogarty Senior International Fellow (TW00790). Mrs. H. Foght and Mrs. M. Deckert are thanked for their skillful, technical assistance. 


\section{References}

1. Mogensen CE, Vittinghus E (1975) Urinary albumin excretion during exercise in juvenile diabetes. Scand J Clin Lab Invest 35: 295-300

2. Viberti GC, Jarrett RJ, McCartney M, Keen H (1978) Increased glomerular permeability to albumin induced by exercise in diabetic subjects. Diabetologia 14: 293-300

3. Poortmans J, Dorchy H, Toussaint D (1982) Urinary excretion of total proteins, albumin and B-2 microglobulin during rest and exercise in diabetic adolescents with and without retinopathy. Diabetes Care 5: 617-623

4. Hermansson G, Ludvigsson J (1980) Renal function and blood pressure reaction during exercise in diabetic and non-diabetic children and adolescents. Acta Paediatr Scand (Supp) 283: 86-94

5. Christensen CK (1984) Abnormal albuminuria and blood-pressure rise in incipient diabetic nephropathy induced by exercise. Kidney Int 25: 819-823

6. Stalder G, Schmidt R, Wulff MV (1960) Funktionelle mikroangiopathie der Nieren beim behandelten Diabetes Mellitus im Kindesalter. Dtsch Med Wochenschr 85: 346-350

7. Ditzel J, Junker K (1972) Abnormal glomerular filtration rate, renal plasma flow, and renal protein excretion in recent and shortterm diabetics. Br Med J 2: 13-19

8. Mogensen CE (1972) Kidney function and glomerular permeability to macromolecules in juvenile diabetes (thesis). Dan Med Bull 19 (Suppl): 1-40

9. Christiansen JS, Gammelgaard J, Frandsen $M$ and Parving $\mathrm{H}-\mathrm{H}$ (1981) Increased kidney size, glomerular filtration rate and renal plasmaflow in short-term insulin-dependent diabetics. Diabetologia $20: 451-456$

10. Vittinghus E, Mogensen CE (1981) Albumin excretion and renal hemodynamic response to physical exercise in normal and diabetic man. Scand J Clin Lab Invest 41: 627-632

11. Mogensen CE (1971) Urinary albumin excretion in early and longterm juvenile diabetes. Scand J Clin Lab Invest 28: 183-193

12. Feldt-Rasmussen B, Mathisen ER (1984) Variability of urinary albumin excretion in incipient diabetic nephropathy. Diabetic $\mathrm{Ne}-$ phropathy $3: 101-103$

13. Hemmingsen L, Skaarup P (1975) The 24-hour excretion of plasmaproteins in the urine of apparently healthy subjects. Scand $J$ Clin Lab Invest 35: 347-353

14. Mogensen CE, Christensen CK, Vittinghus E (1983) The stages in diabetic renal disease. Diabetes 32 (Suppl 2): 64-78

15. Viberti GC, Mogensen CE, Keen H, Jacobsen FK, Jarrett RJ, Christensen CK (1982) Urinary excretion of albumin in normal man. The effect of water loading. Scand J Clin Lab Invest 42: 147-151

16. Karlefors T (1966) Haemodynamic studies in male diabetics. Acta Med Scand (Suppl) 449:45-80

17. Smith WH (1951) The Kidney. Oxford University Press, New York, pp 41-42

18. Mogensen CE (1971) Glomerular filtration rate and renal plasmaflow in short-term and long-term juvenile diabetes mellitus. Scand J Clin Lab Invest 28: 91-100
19. Bucht H, Ek J, Eliasch H, Holmgren A, Josephsen B and Werkó L (1953) The effects of exercise in the recumbent position on the renal circulation and sodium excretion in normal individuals. Acta Physiol Scand 28:95-100

20. Åstrand P-O and Saltin B (1961) Oxygen uptake during the first minutes of heavy muscular exercise. J Appl Physiol 16 (6); 971-976

21. Svendsen PAa, Christiansen JS, Søegaard U, Welinder BA, Nerup J (1980) Rapid changes in chromatographically determined haemoglobin $\mathrm{A}_{1 \mathrm{c}}$ induced by short-term changes in glucose concentration. Diabetologia 19:130-136

22. Keen H, Chlouverakis C (1963) An immunoassay method for urinary albumin at low concentration. Lancet 2:913-916

23. Ewing DJ, Clarke BF (1982) Diagnosis and management of diabetic autonomic neuropathy. Br Med J 285: 916-918

24. Viberti GC, Hill RD, Jarrett RJ, Argyropoulos A, Mahmud U, Keen H (1982) Microalbuminuria as a predictor of clinical nephropathy in insulin-dependent diabetes mellitus. Lancet 1: $1430-1432$

25. Mathiesen ER, Oxenbøll B, Johansen K, Svendsen PAa, Deckert T (1984) Incipient neprhopathy in Type 1 (insulin-dependent) diabetes. Diabetologia 26: 406-410

26. Mogensen CE, Christensen CK (1984) Predicting diabetic nephropathy in insulin-dependent patients. $\mathrm{N}$ Engl. J Med 311: 89-93

27. Parving H-H, Oxenbøll B, Svendsen PAa, Christiansen JS, Andersen AR (1982) Early detections of patients at risk of developing diabetic nephropathy. A longitudinal study of urinary albumin excretion. Acta Endocrinol 100: 550-555

28. Parving H-H, Andersen AR, Smidt U, Frisberg B, Svendsen PAa (1981) Reduced albuminuria during early and aggressive antihypertensive treatment of insulin-dependent diabetic patients with diabetic nephropathy. Diabetes Care 4: 459-463

29. Mogensen CE (1982) Long-term antihypertensive treatment inhibiting progression of diabetic nephropathy. Br Med J 285:685-688

30. Parving H-H, Kastrup H, Smidt UM, Andersen AR, Feldt-Rasmussen B, Sandahl Christiansen J (1984) Impaired autoregulation of glomerular filtration rate in Type 1 (insulin-dependent) diabetic patients with nephropathy. Diabetologia 27: 547-552

31. Wiseman M, Viberti GC, Mackintosh D, Jarrett RJ, Keen H (1984) Glycaemia, arterial pressure and microalbuminuria in Type 1 (insulin-dependent) diabetes mellitus. Diabetologia 26: 401-405

32. Hostetter TH, Rennke HG, Brenner BM (1982) The case for intrarenal hypertension in the initiation and progression of diabetic and other glomerulopathies. Am J Med 72: 375-383

33. Parving $\mathrm{H}-\mathrm{H}$, Viberti GC, Keen $\mathrm{H}$, Christiansen IS, Lassen NA (1983) Hemodynamic factors in the genesis of diabetic microangiopathy. Metabolism 32: 943-949

Received: 5 October 1984

and in revised form: 29 May 1985

Dr. Bo Feldt-Rasmussen

Steno Memorial Hospital

DK-2820 Gentofte

Denmark 